\title{
Behandling av hjerteinfarkt i Kina
}

Stadig flere pasienter med ST-elevasjonsinfarkt i Kina blir innlagt

og behandlet i sykehus, men det er fortsatt mange som ikke får optimal behandling.

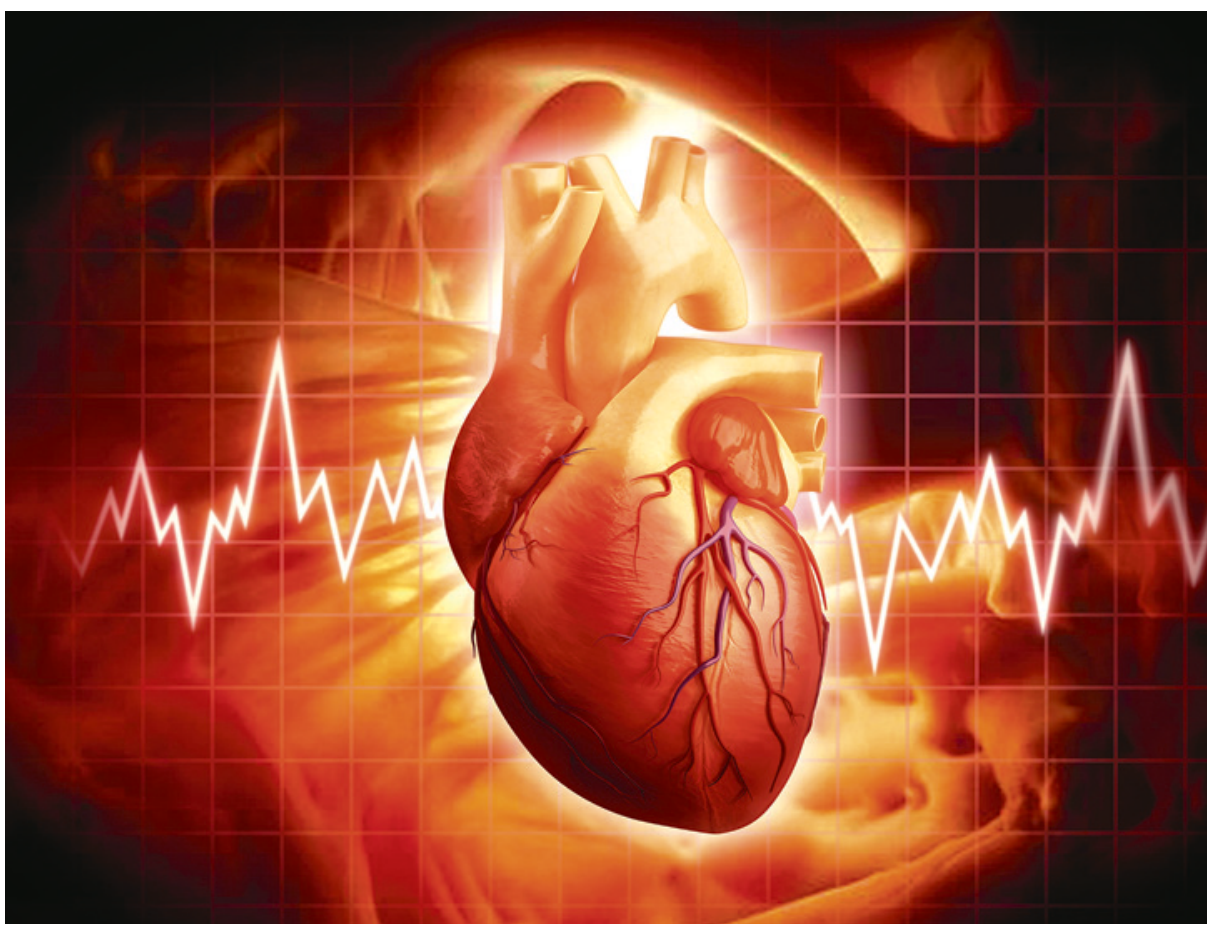

Illustrasjonsfoto: Sciencephoto/NTB scanpix

I en retrospektiv studie er behandling og utfall ved hjerteinfarkt med ST-elevasjon undersøkt (1). Studien omfattet over 12000 pasienter som ble innlagt ved kinesiske sykehus i 2001, 2006 og 2011. Estimert antall sykehusinnleggelser for hjerteinfarkt med ST-elevasjon i Kina økte fra 3,7 per 100000 innbyggere i 2001 til 15,8 per 100000 innbyggere i 2011.

Andelen pasienter uten kontraindikasjon som fikk acetylsalisylsyre innen 24 timer økte fra $79,3 \%(95 \% \mathrm{KI} 77,3-81,3)$ i 2001 til $91,2 \%(95 \%$ KI 90,5-91,9) i 2011. Klopidogrel ble gitt til 1,5\% av pasientene uten kontraindikasjon i 2001, mens dette gjaldt $80,7 \%$ i 2011. Bruken av primær perkutan koronar intervensjon (PCI) hos pasienter uten kontraindikasjon økte fra $10,2 \%$ av i 2001 til $27,6 \%$ i 2011 , mens færre fikk trombolytisk behandling.

- Studien illustrerer at Kina beveger seg raskt i vår retning. Med bedre levestandard kommer livsstilsykdommer, og med økte ressurser en behandling som likner mer på det som er vanlig hos oss, sier kardiolog Kjell Andersen ved Sykehuset Innlandet, Hamar.

- Økningen fra 3,7 til 15,8 ST-elevasjonsinfarkter per 100000 innbyggere kan være uttrykk både for bedre diagnostikk og et bedre helsetilbud og økt reell forekomst. Akutt revaskularisering viser dreining fra trombolytisk behandling til primær perkutan koronar intervensjon, den totale andelen på ca. $55 \%$ er ikke økt i perioden. Utfordringen med å øke denne andelen er åpenbart enda større enn hos oss, sier Andersen.

\section{Matilde Risopatron Berg}

Sykehuset Innlandet, Hamar

\section{Litteratur}

1. Li J, Li X, Wang $Q$ et al. ST-segment elevation myocardial infarction in China from 2001 to 2011 (the China PEACE-Retrospective Acute Myocardial Infarction Study): a retrospective analysis of hospital data. Lancet 2014. E-publisert 23.6. 